\title{
EDUCATING THE RURAL LEGISLATOR
}

\author{
BY WILLIAM C. CULKINS I \\ Cincinnati
}

M

AYOR SPIEGEL of Cincinnati has just appointed a rapid transit commission, to devise a rapid transit system for Cincinnati at an estimated cost of from $\$ 6,000,000$ to $\$ 10,000,000$.

It was appointed under an enabling act passed by the last Ohio legislature, and thereby hangs a tale of unusual interest to those interested in the business and civic legislative problems of the country.

During the winter of 1914-1915 it was necessary for the Cincinnati chamber of commerce and other business and civic organizations representing 7,000 members, to send two special delegations of more than 100 each to the state capitol on the subject of rapid transit. The men who composed these delegations were obliged to neglect their ordinary business on these occasions and spend their time visiting the governor of Ohio, the floor leaders of both leading political parties in senate and house, and others influential in the passing of laws. They were obliged to demonstrate to the members of the legislature that the people of Cincinnati were heart and soul for the solution of the problem of rapid intercommunication within their city. Even then the rapid transit measure hung in the balance for many days and was one of the last acts passed by the legislature prior to its adjournment. As the legislators retired from their chambers after the act had been passed the majority of them were doubtless still dubious as to the policy of giving Cincinnati power to create a rapid transit commission for activity within its own boundaries.

The business men of Cincinnati realized the atmosphere of distrust within the legislative halls, and knew that the measure had passed merely because there had been no active opposition. The law had the support of every active organization in Cincinnati. Business men of other cities, visiting their own legislatures on similar business, have noted the same atmosphere. It remained for the business men of Cincinnati to take the first steps toward removing that influence, which might be described as distinctly antagonistic to the larger cities.

Men of rural communities are almost always found opposed to the activities of those in the cities. Misunderstanding and distrust of one for the other have hampered desirable legislative enactments in every state of the Union. Bitterness has been a common result, and an attitude of armed preparedness between the camps of ruralist and urbanite. The solution of this problem is one of education. Inasmuch as most ruralists are not prepared to expend their own means to secure this education, and no law has yet been passed to enable them to spend state

1 Executive secretary of the Cincinnati Chamber of Commerce. 
moneys for the purpose, the business men of Cincinnati, headed by officials of the Cincinnati chamber of commerce, raised a large fund and entertained the legislators in Cincinnati.

About 200 of the lawmakers and their wives accepted the invitation sent out by the entertainment committee. They were shown the beautiful parks of Cincinnati covering 2,500 acres and given an account of how public funds are expended to improve them. The industrial districts and their needs were shown. The municipal school system, ranging from kindergarten to university, and the new $\$ 4,000,000$ municipal hospital were inspected. The great municipal waterworks system was explained; a review of the city fire and police departments was staged, and they were made acquainted with the intricate mazes of city government and the advisory system of civic and commercial organization committee work in connection with the passage of ordinances. Afterwards they were placed aboard an all steel special train on the Cincinnati Southern line, and borne over this municipally owned railroad 335 miles to Chattanooga. The story of the construction of the railroad by the city to tap the resources of the great south and to afford a market for northern commerce was related to them, and they were shown the city's financial statement which proves that the road has doubled in value since its construction and annually pays the city a revenue of nearly a million dollars.

Of the legislators who took part in the Cincinnati experiment, two thirds came from rural communities. Their knowledge of city affairs in many instances was limited to what they had picked up in the state capitol. Their amazement at the progress of Cincinnati was unconcealed. They were made to realize the betterment of living conditions, the strides made for education, the accomplishment of easy means of intercommunication and the opening up of easy avenues to and from a great trade territory. Finally they were honestly convinced that tax rates which produce a sufficient revenue for the needs of rural communities are entirely insufficient to take care of the needs of metropolitan cities. They partook of the hospitality of Cincinnati's citizens for an entire week, not a moment of which was empty of revelation to them. The statement of one rural legislator just prior to his departure from Cincinnati expresses the sentiments of all who enjoyed this educational experiment: "I don't believe in letting down the bars to permit the cities to make wanton expenditures, but I do believe the legislature of Ohio will in the future have to look much more favorably upon legislation especially applicable to the needs of big cities. We have worked in the dark in the past, basing our votes on our own experiences which we now agree were limited. Our eyes have been opened by what we saw and heard in Cincinnati."

In reviewing the results of this visit of the legislature to Cincinnati, it seems that large cities of other states will find it highly important to 
arrange similar excursions for their legislatures. Possibly they will not be called upon to provide so extensive an entertainment as that given by Cincinnati, but they will at least be obliged to give the country legislator his information about city problems by personal observation. In Cincinnati the citizens are convinced that this experiment has been successful. That it will give excellent results in years to come and will produce a hearty co-operation on the part of the rural legislators who were the city's guests there can be no doubt. Every large city in Ohio will participate in the benefits, and the same plan may be applied effectively in every state in the union. It will serve the purpose of eliminating the feeling of prejudice and distrust confessed to exist between the man of the city and he of the country. The feeling is a mistaken one, the outgrowth of ignorance. Its only remedy is education. The coming of the telephone placed a wedge in this barrier, the making of good roads is doing its part, and the use of the automobile in the country is doing wonders. The final step in our opinion was taken when the legislature of Ohio was given ocular proof of the needs of cities at Cincinnati last September.

\title{
SALEM'S CHARTER EXPERIENCES
}

\author{
BY WINFIELD S. NEVINS \\ Salem, Mass.
}

\begin{abstract}
ALEM, one of the oldest and most conservative cities of the country, 1 has had three kinds of municipal government in less than four years. Incorporated as a city in 1836, under a special charter, it retained that form of government until 1912, when it changed to the "commission form of government." The first charter provided for a mayor and six aldermen-at-large and four councillors from each of the six wards. Only one change was made in that provision down to 1912 ; that was to increase the number of aldermen to seven because of occasional ties with six members. The number of wards has never been changed since the first division in 1836. During the first half century after the adoption of the city charter the governments of Salem were noted for the able men who served the city, many of them men of national reputation. Four of them served in Congress subsequent to serving the city as mayor. Others served with great credit on the judiciary. The very best business and professional men were members of the council. Not until about 1890 was there much deterioration. Then a wave of reaction seemed to sweep over Salem which grew in volume during the next twenty years. Politicians began to seek places in the government to further personal ends. Up to this time nominations had been made by parties or by groups of responsible citizens, who sought the best available men. With the coming of the nomination paper and the Australian ballot, all this changed.
\end{abstract}

